\title{
Experimental determination of Henry's law constants of difluoromethane (HFC-32) and the salting-out effects in aqueous salt solutions relevant to seawater
}

\author{
Shuzo Kutsuna \\ National Institute of Advanced Industrial Science and Technology (AIST), 16-1 Onogawa, Tsukuba, 305-8569, Japan \\ Correspondence to: Shuzo Kutsuna (s-kutsuna@aist.go.jp)
}

Received: 23 January 2017 - Discussion started: 8 February 2017

Revised: 11 May 2017 - Accepted: 19 May 2017 - Published: 21 June 2017

\begin{abstract}
Gas-to-water equilibrium coefficients, $K_{\text {eq }}^{\mathrm{S}}$ (in $\left.\mathrm{M} \mathrm{atm}^{-1}\right)$, of difluoromethane $\left(\mathrm{CH}_{2} \mathrm{~F}_{2}\right)$, a hydrofluorocarbon refrigerant (HFC-32), in aqueous salt solutions relevant to seawater were determined over a temperature $(T)$ range from 276 to $313 \mathrm{~K}$ and a salinity $(S)$ range up to $51 \%$ o by means of an inert-gas stripping method. From the van't Hoff equation, the $K_{\text {eq }}^{\mathrm{S}}$ value in water, which corresponds to the Henry's law constant $\left(K_{\mathrm{H}}\right)$, at $298 \mathrm{~K}$ was determined to be $0.065 \mathrm{M} \mathrm{atm}^{-1}$. The salinity dependence of $K_{\text {eq }}^{\mathrm{S}}$ (the salting-out effect), $\ln \left(K_{\mathrm{H}} / K_{\text {eq }}^{\mathrm{S}}\right)$, did not obey the Sechenov equation but was proportional to $S^{0.5}$. Overall, the $K_{\text {eq }}^{\mathrm{S}}(T)$ value was expressed by $\ln \left(K_{\mathrm{eq}}^{\mathrm{S}}(T)\right)=-49.71+\left(77.70-0.134 \times S^{0.5}\right) \times(100 / T)$ $+19.14 \times \ln (T / 100)$. By using this equation in a lowertropospheric semi-hemisphere $\left(30-90^{\circ} \mathrm{S}\right)$ of the Advanced Global Atmospheric Gases Experiment (AGAGE) 12-box model, we estimated that 1 to $4 \%$ of the atmospheric burden of $\mathrm{CH}_{2} \mathrm{~F}_{2}$ resided in the ocean mixed layer and that this percentage was at least $4 \%$ in the winter; dissolution of $\mathrm{CH}_{2} \mathrm{~F}_{2}$ in the ocean may partially influence estimates of $\mathrm{CH}_{2} \mathrm{~F}_{2}$ emissions from long-term observational data of atmospheric $\mathrm{CH}_{2} \mathrm{~F}_{2}$ concentrations.
\end{abstract}

\section{Introduction}

Hydrofluorocarbons (HFCs) have been developed as replacements for chlorofluorocarbons and hydrochlorofluorocarbons (HCFCs) to protect the stratospheric ozone layer from depletion. In particular, difluoromethane (HFC-32, $\mathrm{CH}_{2} \mathrm{~F}_{2}$ ) has been used as a refrigerant to replace $\mathrm{HCFC}-22\left(\mathrm{CHClF}_{2}\right)$ : azeotropic mixtures of $\mathrm{CH}_{2} \mathrm{~F}_{2}$ with HFC-125 $\left(\mathrm{CHF}_{2} \mathrm{CF}_{3}\right)$ and HFC-134a $\left(\mathrm{CH}_{2} \mathrm{FCF}_{3}\right)$ have been used as refrigerants for air-conditioning and refrigeration for a few decades, and $\mathrm{CH}_{2} \mathrm{~F}_{2}$ alone has recently been used as a refrigerant for airconditioning.

However, HFCs can act as greenhouse gases, and thus there is concern about emissions of $\mathrm{CH}_{2} \mathrm{~F}_{2}$ and other HFCs to the atmosphere, where they can accumulate and contribute to global warming (IPCC, 2013). Observational data from the Advanced Global Atmospheric Gases Experiment (AGAGE) indicate that the atmospheric concentration of $\mathrm{CH}_{2} \mathrm{~F}_{2}$ has been increasing every year since 2004; in 2012, the global mean mole fraction of $\mathrm{CH}_{2} \mathrm{~F}_{2}$ was $6.2 \pm 0.2 \mathrm{ppt}$ (parts per trillion), and the rate of increase was $1.1 \pm 0.04 \mathrm{ppt} \mathrm{yr}^{-1}$ $\left(17 \% \mathrm{yr}^{-1}\right)$ (O'Doherty et al., 2014). By using AGAGE data in combination with a chemical transport model such as the AGAGE 12-box model (Cunnold et al., 1994; Rigby et al., 2013) and a value of 5.1 years as the atmospheric lifetime of $\mathrm{CH}_{2} \mathrm{~F}_{2}$, O'Doherty et al. (2014) estimated the global emission rate of $\mathrm{CH}_{2} \mathrm{~F}_{2}$ in 2012 to be $21 \pm 11 \mathrm{Gg} \mathrm{yr}^{-1}$ with an increase rate of $14 \pm 11 \% \mathrm{yr}^{-1}$. Such estimates on the basis of long-term observational data such as the AGAGE and the National Oceanic and Atmospheric Administration Global Monitoring Division (NOAA GMD) network are called topdown estimates and have been shown to provide an independent and effective method for assessing the accuracy of globally and regionally aggregated reductions or increases in emissions of individual HFCs, as well as other greenhouse gases, compiled from national reports to the United Nations Framework Convention on Climate Change (e.g., Prinn et al., 2000; Lunt et al., 2015; Montzka et al., 2015). 
The atmospheric lifetimes of HFCs are thus related to their estimated emission rates. The currently accepted value of the atmospheric lifetime of $\mathrm{CH}_{2} \mathrm{~F}_{2}$, which was revised in 2014 (Carpenter et al., 2014), is 5.4 years. The partial atmospheric lifetime of $\mathrm{CH}_{2} \mathrm{~F}_{2}$ with respect to gas-phase reactions with $\mathrm{OH}$ in the troposphere is 5.5 years and that with respect to stratospheric removal processes is 124 years. Other processes, such as dissolution in seawater, are not considered to contribute significantly to the atmospheric removal of $\mathrm{CH}_{2} \mathrm{~F}_{2}$. Yvon-Lewis and Butler (2002) estimated partial atmospheric lifetimes of some HCFCs and HFCs with respect to irreversible dissolution in seawater by using physicochemical properties such as solubility and aqueous reaction rates, as well as meteorological data such as temperature and wind speed over the ocean in grids. Their estimates indicated that dissolution in seawater is not a significant sink of the HCFCs and HFCs that were evaluated in the study. Because no aqueous reactions of $\mathrm{CH}_{2} \mathrm{~F}_{2}$ have yet been observed under environmental conditions, the dissolution of $\mathrm{CH}_{2} \mathrm{~F}_{2}$ in seawater is considered to be reversible and cannot serve as a sink of $\mathrm{CH}_{2} \mathrm{~F}_{2}$. However, because $\mathrm{CH}_{2} \mathrm{~F}_{2}$ is more soluble in water than HCFCs and other HFCs (Sander, 2015), even reversible dissolution of $\mathrm{CH}_{2} \mathrm{~F}_{2}$ in seawater might influence a top-down estimate of $\mathrm{CH}_{2} \mathrm{~F}_{2}$ emission rates.

The objective of the present study is to experimentally determine the seawater solubility of $\mathrm{CH}_{2} \mathrm{~F}_{2}$, which is a physicochemical property necessary for estimating the residence ratio of $\mathrm{CH}_{2} \mathrm{~F}_{2}$ in the ocean when the ocean mixed layer is at solubility equilibrium with the atmosphere. Specifically, the Henry's law constants, $K_{\mathrm{H}}$ (in M atm ${ }^{-1}$ ), of $\mathrm{CH}_{2} \mathrm{~F}_{2}$ and the salting-out effects of seawater-relevant ions on $\mathrm{CH}_{2} \mathrm{~F}_{2}$ solubility were experimentally determined. Values of $K_{\mathrm{H}}$ for $\mathrm{CH}_{2} \mathrm{~F}_{2}$ have been reported in some review papers (Sander, 2015; Clever et al., 2005). The largest and smallest values at $298 \mathrm{~K}$ differ from each other by a factor of approximately 3 : $0.87 \mathrm{M} \mathrm{atm}^{-1}$ (Sander, 2015; Yaws and Yang, 1992) and $0.30 \mathrm{M} \mathrm{atm}^{-1}$ (Clever et al., 2005; Miguel et al., 2000). To the author's knowledge, no data on the salting-out effects of seawater-relevant ions on $\mathrm{CH}_{2} \mathrm{~F}_{2}$ solubility have been reported.

First, the values of $K_{\mathrm{H}}$ for $\mathrm{CH}_{2} \mathrm{~F}_{2}$ were determined over the temperature range from 276 to $313 \mathrm{~K}$ by means of an inert-gas stripping (IGS) method. The $K_{\mathrm{H}}$ values were also determined over the temperature range from 313 to $353 \mathrm{~K}$ by means of a phase ratio variation headspace (PRV-HS) method. The $K_{\mathrm{H}}$ values obtained using the two methods could be fitted by an equation representing the same temperature dependence. Second, salting-out effects on $\mathrm{CH}_{2} \mathrm{~F}_{2}$ solubility were determined over the temperature range from 276 to $313 \mathrm{~K}$ for test solutions of artificial seawater prepared over the salinity range from 4.5 to $51.5 \%$. The salting-out effects were confirmed for the artificial seawater, but the relationship between $\mathrm{CH}_{2} \mathrm{~F}_{2}$ solubility and salinity of the artificial seawater was found to be unusual in that the excessive free energy for dissolution was not proportional to the salin- ity but rather was represented by an equation involving the 0.5 power of the salinity. Over the salinity range relevant to seawater, the solubility of $\mathrm{CH}_{2} \mathrm{~F}_{2}$ in the artificial seawater could be represented as a function of both salinity and temperature. Third, on the basis of the solubility of $\mathrm{CH}_{2} \mathrm{~F}_{2}$ in seawater determined in this study and a global gridded dataset of monthly mean values of temperature, salinity, and depth of the ocean mixed layer, the amounts of $\mathrm{CH}_{2} \mathrm{~F}_{2}$ dissolved in the ocean mixed layer were estimated in each month for each lower-tropospheric semi-hemisphere of the AGAGE 12-box model.

\section{Experimental setup}

\subsection{Materials}

$\mathrm{CH}_{2} \mathrm{~F}_{2}$ gas (1010 or $1000 \mathrm{ppmv}$ in synthetic air) was purchased from Takachiho Chemical Industrial Co. (Tokyo, Japan). Sodium chloride $(\mathrm{NaCl},>99.5 \%)$, sodium sulfate $\left(\mathrm{Na}_{2} \mathrm{SO}_{4},>99 \%\right)$, magnesium chloride $\left(\mathrm{MgCl}_{2} 6 \mathrm{H}_{2} \mathrm{O}\right.$, $>98 \%)$, calcium chloride $\left(\mathrm{CaCl}_{2} 2 \mathrm{H}_{2} \mathrm{O},>99.9 \%\right)$, and potassium chloride $(\mathrm{KCl},>99.5 \%)$ were purchased from Wako Pure Chemical Industries (Osaka, Japan) and used as supplied. Water was purified with a Milli-Q Gradient A10 system (resistivity $>18$ megohm-cm).

Synthetic artificial seawater was prepared as described by Platford (1965) and was used to evaluate the salting-out effects on the solubility of $\mathrm{CH}_{2} \mathrm{~F}_{2}$ in the ocean. The prepared artificial seawater had the following definite mole ratios: $0.4240 \mathrm{NaCl}, 0.0553 \mathrm{MgCl}_{2}, 0.0291 \mathrm{Na}_{2} \mathrm{SO}_{4}, 0.0105 \mathrm{CaCl}_{2}$, and $0.0094 \mathrm{KCl}$. The ionic strength of the artificial seawater was set to between 0.089 and $1.026 \mathrm{~mol} \mathrm{~kg}^{-1}$ water, that is, at molality base, with each salt at the aforementioned mole ratio; the salinity (in \%o) of this artificial seawater was between 4.45 and $51.53 \%$. This artificial seawater is referred to hereafter as a-seawater.

\subsection{Inert-gas stripping method with a helical plate}

An IGS method (Mackay et al., 1979) was used to determine the solubility of $\mathrm{CH}_{2} \mathrm{~F}_{2}$ in water and aqueous salt solutions. $\mathrm{A} \mathrm{CH}_{2} \mathrm{~F}_{2}$-air-nitrogen mixture (mixing ratio of $\mathrm{CH}_{2} \mathrm{~F}_{2} \sim 10^{-4}$ ) was bubbled into the aqueous solution for a certain time period (e.g., $5 \mathrm{~min}$ ), and then nitrogen gas $\left(\mathrm{N}_{2}\right)$ was bubbled through the resulting aqueous solution containing $\mathrm{CH}_{2} \mathrm{~F}_{2}$, which was stripped from the solution into the gas phase.

The gas-to-liquid partition coefficient (in $\mathrm{M} \mathrm{atm}^{-1}$ ) at temperature $T$ (in $\mathrm{K}$ ), $K_{\text {eq }}(T)$, was calculated from the rate of the decrease in the gas-phase partial pressure according to Eqs. (1) and (2):

$$
\begin{aligned}
& \ln \left(P_{t} / P_{0}\right)=-k_{1} t, \\
& k_{1}=\frac{1}{K_{\mathrm{eq}}(T) R T} \frac{F}{V},
\end{aligned}
$$


where $P_{t} / P_{0}$ is the ratio of the partial pressure of $\mathrm{CH}_{2} \mathrm{~F}_{2}$ at time $t$ to the partial pressure of $\mathrm{CH}_{2} \mathrm{~F}_{2}$ at fixed time $t_{0}$; $k_{1}$ is the first-order decreasing rate constant (in $\mathrm{s}^{-1}$ ); $F$ is the flow rate of $\mathrm{N}_{2}$ (in $\mathrm{dm}^{3} \mathrm{~s}^{-1}$ ); $V$ is the volume of water or aqueous salt solution (in $\mathrm{dm}^{3}$ ); and $R$ is the gas constant $\left(0.0821 \mathrm{dm}^{3}\right.$ atm K$\left.{ }^{-1} \mathrm{~mol}^{-1}\right)$. The $K_{\text {eq }}(T)$ values in water correspond to the Henry's law constants, $K_{\mathrm{H}}(T)$ in molar per unit of standard atmosphere. The $P_{t}$ values typically ranged from $10^{-4}$ to $10^{-6} \mathrm{~atm}$.

A stripping column apparatus with a helical plate was used to strip $\mathrm{CH}_{2} \mathrm{~F}_{2}$. This apparatus was described in detail by Kutsuna and Hori (2008) and is described briefly here. The stripping column consisted of a jacketed Duran glass column $(4 \mathrm{~cm}$ i.d. $\times 40 \mathrm{~cm}$ height $)$ and a glass gas-introduction tube with a glass helix. Water or a-seawater $\left(0.300\right.$ or $\left.0.350 \mathrm{dm}^{3}\right)$ was added to the column for the test solution. The solution was magnetically stirred, and its temperature was kept constant within $\pm 0.2 \mathrm{~K}$ by means of a constant-temperature bath that had both heating and cooling capabilities (NCB2500, EYELA, Tokyo, Japan) and was connected to the water jacket of the column.

Experiments were conducted at nine temperatures in the range of 276 to $313 \mathrm{~K}$. A CH $\mathrm{CH}_{2} \mathrm{~F}_{2}$-air mixture or $\mathrm{N}_{2}$ was introduced near the bottom of the column through a hole $(\sim 1 \mathrm{~mm}$ in diameter) in the gas-introduction tube. The bubbles traveled along the underside of the glass helix from the bottom to the top of the column, at which point they entered the headspace of the column. The gas flow was controlled by means of calibrated mass flow controllers (M100 Series, MKS Japan, Inc., Tokyo, Japan) and was varied between $2.2 \times 10^{-4}$ and $4.4 \times 10^{-4} \mathrm{dm}^{3} \mathrm{~s}^{-1}$ (STP at $25^{\circ} \mathrm{C}$ and one atmospheric pressure).

The volumetric flow rate of the gas $\left(F_{\text {meas }}\right)$ was calibrated with a soap-bubble meter for each experimental run. The soap-bubble meter had been calibrated by means of a highprecision film flow meter SF-1U with VP-2U (Horiba, Kyoto, Japan). Errors in $F_{\text {meas }}$ are within $\pm 1 \%$. To prevent water evaporation from the stripping column, the gas was humidified prior to entering the stripping column passage through a vessel containing deionized water. This vessel was immersed in a water bath at the same temperature as the stripping column. All volumetric gas flows were corrected to prevailing temperature and pressure by Eq. (3) (Krummen et al., 2000). Errors due to this correction are within $\pm 1 \%$. Errors in $F$ are thus within $\pm 1.4 \%$.

$$
F=F_{\text {meas }} \times \frac{P_{\text {meas }}-h_{\text {meas }}}{P_{\mathrm{hs}}-h} \times \frac{T}{T_{\text {meas }}},
$$

where $P_{\text {meas }}$ and $T_{\text {meas }}$ are the ambient pressure and temperature, respectively, at which $F_{\text {meas }}$ was calibrated; $P_{\mathrm{hs}}$ is the headspace total pressure over the test solution in an IGS method experiment with a flow rate of $F$ at temperature of $T$; and $h_{\text {meas }}$ is the saturated vapor pressure, in units of standard atmosphere, of water at $T_{\text {meas }} ; h$ is the saturated vapor pressure, in units of standard atmosphere, of water or a-seawater at $T$. Values of $h_{\text {meas }}$ and $h$ were calculated by the use of Eq. (4), where $S$ is salinity of a-seawater (Weiss and Price, 1980).

$$
\begin{aligned}
h \text { or } h_{\text {meas }} & =\exp \left[24.4543-67.4509 \times\left(\frac{100}{T}\right)-4.8489\right. \\
& \left.\times \ln \left(\frac{T}{100}\right)-0.000544 \times S\right]
\end{aligned}
$$

The purge gas flow exiting from the stripping column was diluted with constant flow of $\mathrm{N}_{2}$ to prevent water vapor from condensing. The $\mathrm{CH}_{2} \mathrm{~F}_{2}$ in the purge gas flow thus diluted was determined by means of gas chromatographymass spectrometry (GC-MS) on an Agilent $6890 \mathrm{~N}$ gas chromatograph with 5973 inert instrument (Agilent Technologies, Palo Alto, CA). A portion of the purge gas containing $\mathrm{CH}_{2} \mathrm{~F}_{2}$ stripped from the test solution was injected into the GC-MS instrument in split mode (split ratio: $1: 30$ ) with a six-port sampling valve (VICI AG, Valco International, Schenkon, Switzerland) equipped with a stainless sampling loop $\left(1.0 \mathrm{~cm}^{3}\right)$. Gas was sampled automatically at intervals of 10 to 11 min during an experimental run (which lasted from 2 to $8 \mathrm{~h}$ ), depending on the decay rate of the partial pressure of $\mathrm{CH}_{2} \mathrm{~F}_{2}$. Peaks due to $\mathrm{CH}_{2} \mathrm{~F}_{2}$ were measured in selectedion mode $\left(m / z=33, \mathrm{CH}_{2} \mathrm{~F}^{+}\right)$. A PoraBOND-Q capillary column $(0.32 \mathrm{~mm}$ i.d. $\times 50 \mathrm{~m}$ length, Agilent Technologies $)$ was used to separate $\mathrm{CH}_{2} \mathrm{~F}_{2}$. The column temperature was kept at $308 \mathrm{~K}$. Helium was used as the carrier gas. The injection port was kept at $383 \mathrm{~K}$.

If $\mathrm{CH}_{2} \mathrm{~F}_{2}$ in the headspace over the test solution is redistributed into the test solution, $k_{1}$ should be represented by Eq. (5) instead of Eq. (2) (Krummen et al., 2000; Brockbank et al., 2013).

$k_{1}=\frac{F}{K_{\mathrm{eq}}(T) R T V+V_{\text {head }}}$,

where $V_{\text {head }}$ is headspace volume over the test solution. In this study, the values of $V_{\text {head }}$ were 0.070 and $0.020 \mathrm{dm}^{3}$ for $V$ values of 0.300 and $0.350 \mathrm{dm}^{3}$, respectively. Equations (6) and (7) are derived from Eqs. (2) and (5), respectively:

$$
\begin{aligned}
& K_{\text {eq }}(T)=\frac{1}{k_{1} R T} \frac{F}{V}, \\
& K_{\text {eq }}(T)=\frac{1}{k_{1} R T} \frac{F}{V}-\frac{V_{\text {head }}}{R T V} .
\end{aligned}
$$

As described in Sect. 3.1, $\mathrm{CH}_{2} \mathrm{~F}_{2}$ in the headspace over the test solution was not expected to be redistributed into the test solution. Hence, Eq. (6) was used to deduce $K_{\text {eq }}(T)$ from $k_{1}$. Errors in $T$ are estimated to be within $\pm 0.2 \mathrm{~K}$. These errors in $T$ may give potential systematic bias of ca. $\pm 1 \%$ $\left(\delta K_{\text {eq }} / K_{\text {eq }}\right)$ where $\delta K_{\text {eq }}$ is the error in the value of $K_{\text {eq }}$. Errors in $F$ are estimated to be less than $1.4 \%$, and these errors may give potential systematic bias of less than $1.4 \%$ $\left(\delta K_{\text {eq }} / K_{\text {eq }}\right)$. Accordingly, for the IGS methods, values of $K_{\text {eq }}$ may have potential systematic bias of ca. $\pm 2 \%$. 
If the redistribution of $\mathrm{CH}_{2} \mathrm{~F}_{2}$ in the headspace to the test solution had occurred, the values determined using Eq. (6) would be overestimated. Errors due to this redistribution are always negative values. The ratio of the errors to the $K_{\text {eq }}$ values $(\%)$ is $\frac{100 k_{1} V_{\text {head }}}{F}$. Values of this ratio increase as values of $K_{\text {eq }}$ decrease. Under the experimental conditions here, this ratio is calculated to be from $-2.0 \%$ for water at $3.0^{\circ} \mathrm{C}$ to $-6.5 \%$ for a-seawater at $51.534 \%$ and $39.5^{\circ} \mathrm{C}$.

\subsection{Phase ratio variation headspace method}

The $K_{\mathrm{H}}$ values of $\mathrm{CH}_{2} \mathrm{~F}_{2}$ in water were also determined by means of the PRV-HS method (Ettre et al., 1993) for comparison with the results obtained using the above-described IGS method. The PRV-HS method experiments were performed over the temperature range from 313 to $353 \mathrm{~K}$ at $10 \mathrm{~K}$ intervals because the headspace temperature in the equipment used here could not be controlled at less than $313 \mathrm{~K}$. The experimental procedure was the same as that described in detail previously (Kutsuna, 2013), and it is described briefly here.

The determination was carried out by GC-MS on an Agilent 6890N gas chromatograph with 5973 inert instrument (Agilent Technologies) equipped with an automatic headspace sampler (HP7694, Agilent Technologies). The headspace samples were slowly and continuously shaken by a mechanical setup for the headspace equilibration time ( $1 \mathrm{~h}$; see below), and then the headspace gas $\left(1 \mathrm{~cm}^{3}\right)$ was injected into the gas chromatograph in split mode (split ratio: $1: 30$ ). The conditions used for GC-MS were the same as those described in Sect. 2.2.

Headspace samples containing five different amounts of $\mathrm{CH}_{2} \mathrm{~F}_{2}$ and six different volumes of water were prepared for an experimental run at each temperature as follows (30 samples total). Volumes $\left(V_{i}\right)$ of $1.5,3.0,4.5,6.0,7.5$, and $9.0 \mathrm{~cm}^{3}$ of deionized water were pipetted into six headspace vials with a total volume $\left(V_{0}\right)$ of $21.4 \mathrm{~cm}^{3}\left(V_{i} / V_{0}=0.070,0.140\right.$, $0.210,0.280,0.350$, and 0.421 , respectively). Five sets of six headspace vials were prepared and sealed. A prescribed volume $\left(v_{j}\right)$ of a standard gas mixture of $\mathrm{CH}_{2} \mathrm{~F}_{2}$ and air was added to each set of five vials containing the same volume $\left(V_{i}\right)$ of water by means of a gas-tight syringe $\left(v_{j}=0.05\right.$, $0.10,0.15,0.20$, or $\left.0.25 \mathrm{~cm}^{3}\right)$. The headspace partial pressure of $\mathrm{CH}_{2} \mathrm{~F}_{2}$ thus prepared ranged from $10^{-5}$ to $10^{-6}$ atm.

The time required for equilibration between the headspace and the aqueous solution was determined by analyzing the headspaces over the test samples as a function of time until steady-state conditions were attained. In Fig. S1 in the Supplement, the relative signal intensities of the GC-MS peaks for $\mathrm{CH}_{2} \mathrm{~F}_{2}$, that is, the ratio of the headspace partial pressure at time $t$ to that at $60 \mathrm{~min}\left(P_{t} / P_{60}\right)$, are plotted against the time $\left(t_{\mathrm{h}}\right)$ during which samples were placed in the headspace oven. The plot shows that the peak area did not change after $60 \mathrm{~min}$ (Fig. S1). Therefore, the headspace equilibration time was set at $1 \mathrm{~h}$ for all the measurements.
If $P_{i j}$ is the equilibrium partial pressure (in atm) of a $\mathrm{CH}_{2} \mathrm{~F}_{2}$ sample in a vial with volume $V_{0}$ (in $\mathrm{cm}^{3}$ ) containing a volume $V_{i}\left(\right.$ in $\mathrm{cm}^{3}$ ) of water and a volume $v_{j}$ (in $\mathrm{cm}^{3}$ ) of a $\mathrm{CH}_{2} \mathrm{~F}_{2}$ gas mixture and if $P_{j}$ is the equilibrium partial pressure (in atm) of $\mathrm{CH}_{2} \mathrm{~F}_{2}$ in a sample containing volume $v_{j}$ (in $\mathrm{cm}^{3}$ ) of a $\mathrm{CH}_{2} \mathrm{~F}_{2}$ gas mixture without water, then Eq. (8) applies:

$\frac{P_{j} V_{0}}{R T}=K_{\mathrm{eq}}(T) P_{i j} V_{i}+\frac{P_{i j}\left(V_{0}-V_{i}\right)}{R T}$.

Because the signal peak area of $\mathrm{CH}_{2} \mathrm{~F}_{2}\left(S_{i j}\right)$ at partial pressure $P_{i j}$ is expected to be proportional to $v_{j}$ for each set of samples with the same $V_{i}$, a plot of $S_{i j}$ vs. $v_{j}$ should be a straight line that intercepts the origin:

$S_{i j}=L_{i} v_{j}$

The slope of the line, $L_{i}$, corresponds to $S_{i j}$ at $v_{j}=1.0 \mathrm{~cm}^{3}$. If $L$ is the slope corresponding to $P_{i}$ at $V_{i}=0$, then

$\frac{1}{L_{i}}=\frac{1}{L}+\frac{R T K_{\mathrm{eq}}(T)-1}{L} \frac{V_{i}}{V_{0}}$.

Plotting $1 / L_{i}$ against $V_{i} / V_{0}$ gives an intercept of $1 / L$ and a slope of $\left[R T K_{\text {eq }}(T)-1\right] / L$, and $K_{\text {eq }}(T)$ can be obtained from these two values. Therefore, $K_{\text {eq }}(T)$ can be determined by recording the peak area $S_{i j}$, deriving $L_{i}$ from a plot of $S_{i j}$ vs. $v_{j}$ and then applying regression analysis to plots of $1 / L_{i}$ vs. $V_{i} / V_{0}$ with respect to Eq. (10).

Furthermore, values of $K_{\text {eq }}(T)$ and errors in them were determined by the nonlinear fitting of the data of $L_{i}$ and $V_{i} / V_{0}$ by means of Eq. (11), which was obtained from Eq. (10):

$L_{i}=\frac{L}{1+\left(R T K_{\mathrm{eq}}(T)-1\right) \frac{V_{i}}{V_{0}}}$.

Errors in $T$ are estimated to be within ca. $2 \mathrm{~K}$. These errors in $T$ may give a potential systematic bias of ca. $\pm 4 \%$ $\left(\delta K_{\text {eq }} / K_{\text {eq }}\right)$ at $313 \mathrm{~K}$ and ca. $\pm 3 \%\left(\delta K_{\text {eq }} / K_{\text {eq }}\right)$ at $353 \mathrm{~K} . \mathrm{Er}-$ rors in $V_{0}$ are estimated to be less than $1 \%$, and these errors may give a potential systematic bias of less than $1 \%$ $\left(\delta K_{\text {eq }} / K_{\text {eq }}\right)$. Accordingly, for the PRV-HS methods, values of $K_{\text {eq }}$ may have a potential systematic bias of ca. $\pm 4 \%$.

\section{Results and discussion}

\subsection{Determination of Henry's law constants}

In the IGS method experiment, an aqueous solution was purged with $\mathrm{N}_{2}$ to strip $\mathrm{CH}_{2} \mathrm{~F}_{2}$ from the solution into the $\mathrm{N}_{2}$ purge gas flow, and the partial pressure of $\mathrm{CH}_{2} \mathrm{~F}_{2}\left(P_{t}\right)$ in the $\mathrm{N}_{2}$ purge gas flow decreased with time. Typically, it took 20-100 min, depending on the purge gas flow rate and the temperature of the solution, for the decrease to show a firstorder time profile. From the first-order time profile of $P_{t}$ for 

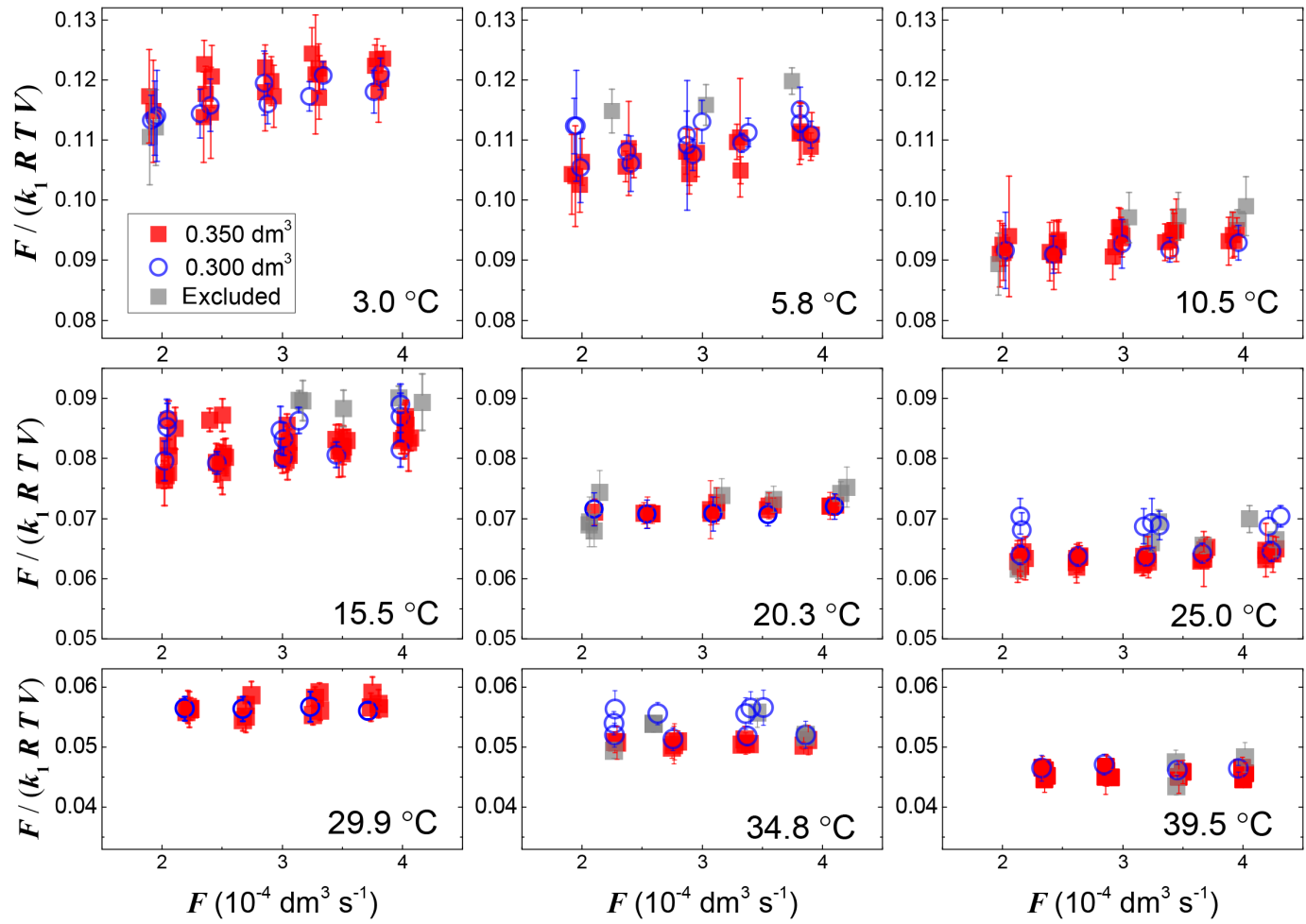

Figure 1. Plots of values of $F /\left(k_{1} R T V\right)$ against $F$ at each temperature for 0.350 and $0.300 \mathrm{dm}^{3}$ of deionized water. Error bars represent $2 \sigma$ due to errors in values of $k_{1}$ as described in Sect. S2. Grey symbols represent the data excluded for calculating the average.

the following period of 2-7 h, during which $P_{t}$ typically decreased by 2 orders of magnitude, the first-order decreasing rate constant, $k_{1}$, was calculated according to Eq. (1). Values of $k_{1}$ were obtained at different volumes of deionized water $(V)$, various purge gas flow rates $(F)$, and various temperatures. Figure $\mathrm{S} 2$ shows an example of the time profile of $P_{t}$ and how to calculate the $k_{1}$ value.

Figure 1 plots values of $F /\left(k_{1} R T V\right)$, the right side of Eq. (6), against $F$ for $V$ values of 0.350 and $0.300 \mathrm{dm}^{3}$ at each temperature $T(\mathrm{~K})$. Table 1 lists the average values of $F /\left(k_{1} R T V\right)$ for $V$ values of 0.350 and $0.300 \mathrm{dm}^{3}$ at each temperature. The data with errors being $>10 \%$ of the data were first excluded. Next, some data were excluded for the calculation of the average so that the remaining data were inside the $2 \sigma$ range. This procedure was iterated until all the data were inside the $2 \sigma$ range. The data points thus excluded were only for $V$ values of $0.350 \mathrm{dm}^{3}$, and there were eight or fewer of them at each temperature.

As is apparent in Fig. 1 and Table 1 , the $F /\left(k_{1} R T V\right)$ values for the two $V$ values $\left(0.350\right.$ and $\left.0.300 \mathrm{dm}^{3}\right)$ agreed at each temperature. This agreement strongly suggests that $K_{\text {eq }}(T)$ is represented by Eq. (6) rather than by Eq. (7) because, if Eq. (7) were applicable, the $K_{\text {eq }}(T)$ values calculated for the $V$ value of $0.300 \mathrm{dm}^{3}$ would be inconsistent with those for the $V$ value of $0.350 \mathrm{dm}^{3}$ : the former would be smaller than the latter by $0.007-0.008 \mathrm{M} \mathrm{atm}^{-1}$. Redis- tribution of $\mathrm{CH}_{2} \mathrm{~F}_{2}$ between the headspace and the test solution was probably negligible under the experimental conditions here; hence, values of $K_{\text {eq }}(T)$ should be calculated from Eq. (6) rather than Eq. (7).

The abovementioned agreement also supports the idea that the gas-to-water partitioning equilibrium of $\mathrm{CH}_{2} \mathrm{~F}_{2}$ was achieved under the experimental conditions used for the IGS method. As described later, the achievement of gas-to-water partitioning equilibrium was also supported by comparison of these data with $K_{\mathrm{eq}}(T)$ values obtained using the PRVHS method. Hereafter only values of $F /\left(k_{1} R T V\right)$ for the $V$ value of $0.350 \mathrm{dm}^{3}$ are used to deduce $K_{\text {eq }}(T)$ values. Because the $K_{\text {eq }}(T)$ values in water correspond to the Henry's law constants, $K_{\mathrm{H}}(T)$ in molar per unit of standard atmosphere, $K_{\mathrm{H}}(T)$ is used instead of $K_{\mathrm{eq}}(T)$ in this section.

Figure 2 plots the average $K_{\mathrm{H}}$ values for the $V$ value of $0.350 \mathrm{dm}^{3}$ against $100 / T$. Error bars of the data represent $2 \sigma$ for the average plus potential systematic bias $( \pm 2 \%)$. Figure 2 also displays the $K_{\mathrm{H}}(T)$ values obtained using the PRV-HS method. The results of the PRV-HS experiments are described in the Supplement (Figs. S3 and S4 and Table S1). The $K_{\mathrm{H}}$ value obtained using the PRV-HS experiments at each temperature and its error were estimated at the $95 \%$ confidence level by fitting the two datasets at each temperature (Fig. S4) simultaneously by means of the nonlinear leastsquares method with respect to Eq. (11). Error bars of the 
Table 1. The average of values of $F /\left(k_{1} R T V\right)$ obtained for $V$ values of 0.350 and $0.300 \mathrm{dm}^{3}$ and the $K_{\mathrm{H}}(T)$ value derived from Eq. (13) at each temperature. $N$ represents the number of experimental runs for the average.

\begin{tabular}{|c|c|c|c|c|c|}
\hline \multirow[t]{3}{*}{$T(\mathrm{~K})$} & \multicolumn{4}{|c|}{$F /\left(k_{1} R T V\right)$} & \multirow{3}{*}{$\begin{array}{l}K_{\mathrm{H}}(T)\left(\mathrm{M} \mathrm{atm}^{-1}\right) \\
\text { From Eq. }(13)^{\mathrm{d}, \mathrm{e}}\end{array}$} \\
\hline & \multicolumn{2}{|l|}{$V=0.350$} & \multicolumn{2}{|l|}{$V=0.300$} & \\
\hline & Average $^{\mathrm{a}, \mathrm{b}}$ & $N^{\mathrm{c}}$ & Average $^{\mathrm{a}}$ & $N^{\mathrm{c}}$ & \\
\hline 276.15 & $0.119 \pm 0.006(0.008)$ & $21(2)$ & $0.117 \pm 0.006(0.008)$ & $11(0)$ & $0.119 \pm 0.003(0.005)$ \\
\hline 278.35 & $0.107 \pm 0.005(0.007)$ & $18(3)$ & $0.110 \pm 0.005(0.007)$ & $14(0)$ & $0.111 \pm 0.002(0.004)$ \\
\hline 283.65 & $0.093 \pm 0.003(0.005)$ & $27(5)$ & $0.092 \pm 0.001(0.003)$ & $5(0)$ & $0.094 \pm 0.002(0.004)$ \\
\hline 288.65 & $0.082 \pm 0.006(0.008)$ & $41(5)$ & $0.084 \pm 0.006(0.008)$ & $12(0)$ & $0.082 \pm 0.002(0.004)$ \\
\hline 293.45 & $0.071 \pm 0.001(0.002)$ & $15(8)$ & $0.071 \pm 0.001(0.002)$ & $5(0)$ & $0.072 \pm 0.002(0.003)$ \\
\hline 298.15 & $0.064 \pm 0.002(0.003)$ & $30(6)$ & $0.067 \pm 0.005(0.006)$ & $12(0)$ & $0.065 \pm 0.002(0.003)$ \\
\hline 303.05 & $0.057 \pm 0.003(0.004)$ & $16(0)$ & $0.056 \pm 0.005(0.006)$ & $4(0)$ & $0.058 \pm 0.002(0.003)$ \\
\hline 307.95 & $0.051 \pm 0.001(0.002)$ & $12(6)$ & $0.054 \pm 0.004(0.005)$ & $10(0)$ & $0.052 \pm 0.002(0.003)$ \\
\hline 312.65 & $0.046 \pm 0.001(0.002)$ & $13(3)$ & $0.047 \pm 0.001(0.002)$ & $4(0)$ & $0.048 \pm 0.001(0.002)$ \\
\hline
\end{tabular}

${ }^{a}$ Errors are $2 \sigma$ for the average only. ${ }^{b}$ Number in parentheses represents an error reflecting $2 \sigma$ for the average plus potential systematic bias $( \pm 2 \%) .{ }^{\mathrm{c}}$ Number in parentheses represents number of experimental runs excluded for the average. ${ }^{\mathrm{d}}$ Errors are $95 \%$ confidence level for the regression only. ${ }^{\mathrm{e}}$ Number in parentheses represents an error reflecting errors at the $95 \%$ confidence level for the regression plus potential systematic bias $( \pm 2 \%)$.

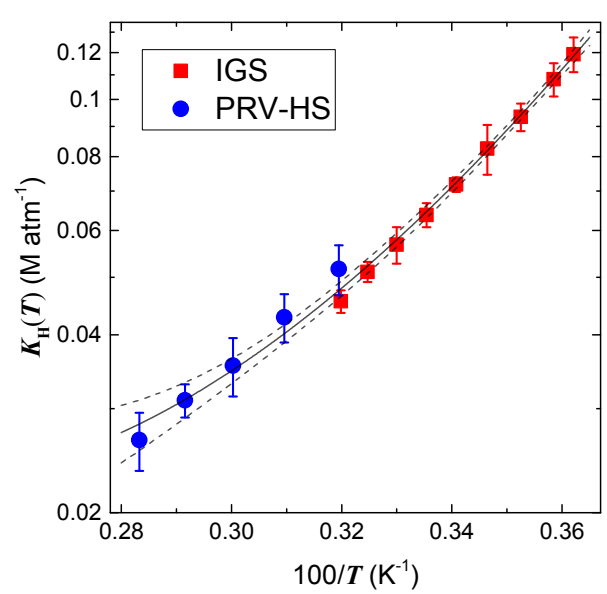

Figure 2. Van't Hoff plot of the $K_{\mathrm{H}}$ values obtained using the IGS method and the PRV-HS method. Solid curve displays the fitting of the data obtained using the IGS method and the PRV-HS method (Eq. 13). Dashed curves display upper and lower $95 \%$ confidence limit of the above fitting by Eq. (12). Error bars of the data by the IGS method represent $2 \sigma$ for the average plus potential systematic bias $( \pm 2 \%)$. Error bars of the data by the PRV-HS method represent errors at the $95 \%$ confidence level for the regression plus potential systematic bias $( \pm 4 \%)$.

data by the PRV-HS method in Fig. 2 represent errors at the $95 \%$ confidence level for the regression plus potential systematic bias $( \pm 4 \%)$.

All the $K_{\mathrm{H}}$ values were regressed with respect to the van't Hoff equation (Eq. 12) with no weighting (Clarke and Glew, 1965; Weiss, 1970):

$K_{\mathrm{H}}(T)=\exp \left(a_{1}+a_{2} \times\left(\frac{100}{T}\right)+a_{3} \times \ln \left(\frac{T}{100}\right)\right)$.
The regression with respect to Eq. (12) gave Eq. (13).

$$
\begin{aligned}
\ln \left(K_{\mathrm{H}}(T)\right) & =-49.71+77.70 \times\left(\frac{100}{T}\right)+19.14 \\
& \times \ln \left(\frac{T}{100}\right)
\end{aligned}
$$

The square root of variance, that is, the standard deviation for each fitting coefficient in Eq. (12), is as follows:

$\delta a_{1}=5.5 ; \delta a_{2}=8.3 ; \delta a_{3}=2.8$.

In Fig. 2, the solid curve was obtained using Eq. (13). The $K_{\mathrm{H}}(T)$ values calculated using Eq. (13) are listed in Table 1. Equation (13) can reproduce the average of $K_{\mathrm{H}}$ values at each temperature within an error of $5 \%$. The dashed lines in Fig. 2 represent $95 \%$ confidence limits of the regression for fitting the $K_{\mathrm{H}}(T)$ values by Eq. (12). Taking into consideration errors in the $K_{\mathrm{H}}$ values, the $K_{\mathrm{H}}$ values obtained using the two methods were within the $95 \%$ confidence limits of the regression by Eq. (12); this result supports the idea that the values determined by the IGS method and the PRV-HS method were accurate.

The Gibbs free energy for the dissolution of $\mathrm{CH}_{2} \mathrm{~F}_{2}$ in water at temperature $T\left(\Delta G_{\mathrm{sol}}(T)\right)$ and the enthalpy for the dissolution of $\mathrm{CH}_{2} \mathrm{~F}_{2}$ in water $\left(\Delta H_{\text {sol }}\right)$ can be deduced from $K_{\mathrm{H}}(T)$ by means of Eqs. (14) and (15):

$$
\begin{aligned}
& \Delta G_{\mathrm{sol}}(T)=\mu_{1}^{\mathrm{o}}(T)-\mu_{\mathrm{g}}^{\mathrm{o}}(T)=-R T \ln \left(K_{\mathrm{H}}(T)\right) \\
& \Delta H_{\mathrm{sol}}(T)=-R \frac{\partial\left[\ln \left(K_{\mathrm{H}}(T)\right)\right]}{\partial(1 / T)},
\end{aligned}
$$

where $\mu_{l}^{\mathrm{O}}(T)$ is the chemical potential of $\mathrm{CH}_{2} \mathrm{~F}_{2}$ under the standard-state conditions at a concentration of $1 \mathrm{M}$ in aqueous solutions at temperature $T$; and $\mu_{\mathrm{g}}^{\mathrm{o}}(T)$ is the chemical 

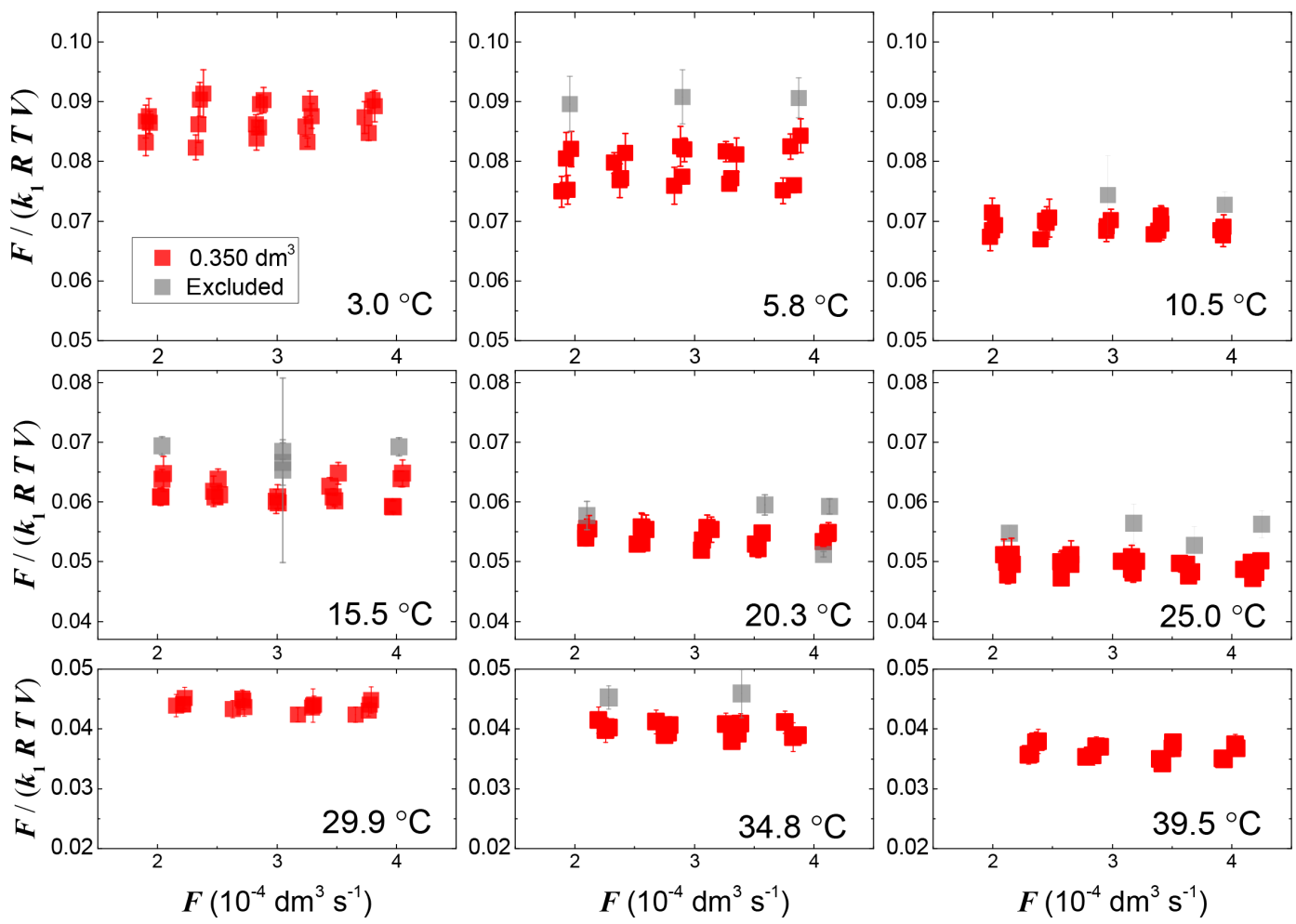

Figure 3. Plots of values of $F /\left(k_{1} R T V\right)$ against $F$ at each temperature for $0.350 \mathrm{dm}^{3}$ of a-seawater at $36.074 \%$. Error bars represent $2 \sigma$ due to errors in the values of $k_{1}$ as described in Sect. S2. Grey symbols represent the data excluded for calculating the average.

potential of $\mathrm{CH}_{2} \mathrm{~F}_{2}$ under the standard-state conditions at 1 atm of partial pressure in the gas phase at temperature $T$. The $K_{\mathrm{H}}(T)$ and $\Delta H_{\mathrm{sol}}(T)$ values at $298.15 \mathrm{~K}$ were calculated by means of Eqs. (13) and (15) and are listed in Table 2. $K_{\mathrm{H}}(298.15)$ is represented by $K_{\mathrm{H}}^{298}$ hereafter.

Table 2 also lists literature values of $K_{\mathrm{H}}^{298}$ and $\Delta H_{\mathrm{sol}}$ at $298.15 \mathrm{~K}$ for $\mathrm{CH}_{2} \mathrm{~F}_{2}$ reported in two reviews (Clever et al., 2005; Sander, 2015) and by Anderson (2011); the units of the literature data were converted to $\mathrm{M} \mathrm{atm}^{-1}$ for $K_{\mathrm{H}}^{298}$ and kilojoule per mole for $\Delta H_{\text {sol }}$. The $K_{\mathrm{H}}^{298}$ value determined in this study was 6-7\% smaller than the values reported by Maaßen (1995), Reichl (1995), and Anderson (2011), whereas the value reported by Yaws and Yang (1992), that reported by Hilal et al. (2008), and that reported by Miguel et al. (2000) were 1.3, 1.3, and 0.46 times, respectively, as large as the value determined here. The absolute value of $\Delta H_{\mathrm{sol}}$ at $298.15 \mathrm{~K}$ determined here was $1.4-3.4 \mathrm{~kJ} \mathrm{~mol}^{-1}$ less than the values determined by Maaßen (1995), Reichl (1995), Kühne et al. (2005), and Anderson (2011), whereas it was $10 \mathrm{~kJ} \mathrm{~mol}^{-1}$ less than the value reported by Miguel et al. (2000).

\subsection{Determination of salting-out effects in artificial seawater}

The solubility of $\mathrm{CH}_{2} \mathrm{~F}_{2}$ in a-seawater (Sect. 2.1) was determined by means of the IGS method (Sect. 2.2). According to
Table 2. $K_{\mathrm{H}}^{298}$ and $\Delta H_{\text {sol }}$ values derived from Eqs. (13) and (15), along with literature data for $K_{\mathrm{H}}^{298}$ and $\Delta H_{\mathrm{sol}}$.

\begin{tabular}{lrl}
\hline $\begin{array}{l}K_{\mathrm{H}}^{298} \\
\left(\mathrm{M} \mathrm{atm}^{-1}\right)\end{array}$ & $\begin{array}{r}\Delta H_{\text {sol }} \\
\left(\mathrm{kJ} \mathrm{mol}^{-1}\right)\end{array}$ & \\
\hline 0.065 & -17.2 & This work \\
0.070 & -20 & Maaßen $(1995)^{\mathrm{a}}$ \\
0.070 & -19 & Reichl $(1995)^{\mathrm{a}}$ \\
$0.069^{\mathrm{c}}$ & -20.6 & Anderson $(2011)$ \\
0.085 & & Hilal et al. $(2008)^{\mathrm{a}}$ \\
& $-18.6,-19.7$ & Kühne et al. $(2005)^{\mathrm{a}}$ \\
0.087 & & Yaws (1999) $^{\mathrm{a}}$ \\
0.087 & & Yaws and Yang $(1992)^{\mathrm{a}}$ \\
0.030 & -27.2 & Miguel et al. $(2000)^{\mathrm{b}}$ \\
\hline
\end{tabular}

${ }^{a}$ Reviewed by Sander (2015). ${ }^{b}$ Reviewed by Clever et al. (2005). ${ }^{c}$ The value was obtained by extrapolation of the data reported at

284.15-296.15 K (Supplement in Anderson, 2011) with respect to the van't Hoff equation.

Eq. (6), the $K_{\text {eq }}(T)$ values at an a-seawater salinity of $S$ in per mill were obtained by averaging the $F /\left(k_{1} R T V\right)$ values for the $V$ value of $0.350 \mathrm{dm}^{3}$ at each salinity and temperature in a similar way as described in Sect. 3.1. Figure 3 plots values of $F /\left(k_{1} R T V\right)$ at each temperature against $F$ for $V$ values of $0.350 \mathrm{dm}^{3}$ at an a-seawater salinity of $36.074 \%$. Figures S5S8 represent such plots at an a-seawater salinity of 4.452 , 
Table 3. The average of values of $F /\left(k_{1} R T V\right)$ obtained for $V$ values of $0.350 \mathrm{dm}^{3}$ and the $K_{\text {eq }}^{\mathrm{S}}(T)$ value derived from Eq. (23) at each salinity and temperature. $N$ represents the number of experimental runs for the average.

\begin{tabular}{|c|c|c|c|c|c|c|}
\hline \multirow[t]{3}{*}{$T(\mathrm{~K})$} & \multicolumn{6}{|c|}{$K_{\mathrm{eq}}^{\mathrm{S}}\left(\mathrm{M} \mathrm{atm}^{-1}\right)$} \\
\hline & \multicolumn{3}{|c|}{ Salinity, $4.452 \% 0$} & \multicolumn{3}{|c|}{ Salinity, $8.921 \% \circ$} \\
\hline & Average $^{\mathrm{a}, \mathrm{b}}$ & $N^{\mathrm{c}}$ & Eq. $(23)^{\mathrm{d}, \mathrm{e}}$ & Average $^{\mathrm{a}, \mathrm{b}}$ & $N^{\mathrm{c}}$ & Eq. $(23)^{\mathrm{d}, \mathrm{e}}$ \\
\hline 276.15 & $0.108 \pm 0.006(0.008)$ & $8(0)$ & $0.107 \pm 0.003(0.005)$ & $0.103 \pm 0.006(0.008)$ & $21(0)$ & $0.103 \pm 0.003(0.005)$ \\
\hline 278.35 & $0.099 \pm 0.004(0.006)$ & $12(0)$ & $0.100 \pm 0.002(0.005)$ & $0.095 \pm 0.006(0.008)$ & $26(1)$ & $0.096 \pm 0.002(0.004)$ \\
\hline 283.65 & $0.086 \pm 0.003(0.005)$ & $9(0)$ & $0.085 \pm 0.002(0.004)$ & $0.083 \pm 0.007(0.009)$ & $24(0)$ & $0.082 \pm 0.002(0.004)$ \\
\hline 288.65 & $0.075 \pm 0.004(0.006)$ & $12(0)$ & $0.074 \pm 0.002(0.003)$ & $0.072 \pm 0.005(0.006)$ & $33(0)$ & $0.071 \pm 0.001(0.002)$ \\
\hline 293.45 & $0.065 \pm 0.002(0.003)$ & $10(0)$ & $0.066 \pm 0.002(0.003)$ & $0.063 \pm 0.003(0.004)$ & $27(5)$ & $0.063 \pm 0.002(0.003)$ \\
\hline 298.15 & $0.058 \pm 0.002(0.003)$ & $13(0)$ & $0.059 \pm 0.002(0.003)$ & $0.056 \pm 0.004(0.005)$ & $26(2)$ & $0.056 \pm 0.002(0.003)$ \\
\hline 303.05 & $0.052 \pm 0.001(0.002)$ & $8(0)$ & $0.053 \pm 0.002(0.003)$ & $0.049 \pm 0.004(0.005)$ & $14(6)$ & $0.051 \pm 0.001(0.002)$ \\
\hline 307.95 & $0.047 \pm 0.002(0.003)$ & $13(1)$ & $0.048 \pm 0.001(0.002)$ & $0.046 \pm 0.004(0.005)$ & $23(1)$ & $0.046 \pm 0.001(0.002)$ \\
\hline \multirow[t]{3}{*}{312.65} & $0.042 \pm 0.001(0.002)$ & $7(0)$ & $0.044 \pm 0.001(0.002)$ & $0.040 \pm 0.003(0.004)$ & $12(8)$ & $0.042 \pm 0.001(0.002)$ \\
\hline & \multicolumn{3}{|c|}{ Salinity, $21.520 \%$} & \multicolumn{3}{|c|}{ Salinity, $36.074 \% \circ$} \\
\hline & Average $^{a, b}$ & $N^{\mathrm{c}}$ & Eq. $(23)^{\mathrm{d}, \mathrm{e}}$ & Average $^{\mathrm{a}, \mathrm{b}}$ & $N^{\mathrm{c}}$ & Eq. $(23)^{\mathrm{d}, \mathrm{e}}$ \\
\hline 276.15 & $0.095 \pm 0.006(0.008)$ & $20(0)$ & $0.095 \pm 0.003(0.005)$ & $0.088 \pm 0.005(0.007)$ & $21(0)$ & $0.089 \pm 0.002(0.004)$ \\
\hline 278.35 & $0.087 \pm 0.005(0.007)$ & $22(0)$ & $0.088 \pm 0.002(0.004)$ & $0.079 \pm 0.006(0.008)$ & $20(3)$ & $0.083 \pm 0.002(0.004)$ \\
\hline 283.65 & $0.075 \pm 0.004(0.006)$ & $15(1)$ & $0.076 \pm 0.001(0.003)$ & $0.069 \pm 0.002(0.003)$ & $18(2)$ & $0.071 \pm 0.001(0.002)$ \\
\hline 288.65 & $0.066 \pm 0.004(0.005)$ & $20(0)$ & $0.066 \pm 0.001(0.002)$ & $0.062 \pm 0.004(0.005)$ & $19(4)$ & $0.062 \pm 0.001(0.002)$ \\
\hline 293.45 & $0.058 \pm 0.003(0.004)$ & $14(0)$ & $0.058 \pm 0.001(0.002)$ & $0.054 \pm 0.002(0.003)$ & $19(4)$ & $0.055 \pm 0.001(0.002)$ \\
\hline 298.15 & $0.052 \pm 0.003(0.004)$ & $20(0)$ & $0.052 \pm 0.001(0.002)$ & $0.049 \pm 0.002(0.003)$ & $24(4)$ & $0.049 \pm 0.001(0.002)$ \\
\hline 303.05 & $0.046 \pm 0.003(0.004)$ & $16(0)$ & $0.047 \pm 0.001(0.002)$ & $0.044 \pm 0.002(0.003)$ & $16(0)$ & $0.044 \pm 0.001(0.002)$ \\
\hline 307.95 & $0.042 \pm 0.003(0.004)$ & $16(0)$ & $0.043 \pm 0.001(0.002)$ & $0.040 \pm 0.002(0.003)$ & $15(2)$ & $0.040 \pm 0.001(0.002)$ \\
\hline \multirow[t]{3}{*}{312.65} & $0.038 \pm 0.002(0.003)$ & $16(0)$ & $0.039 \pm 0.001(0.002)$ & $0.036 \pm 0.002(0.003)$ & $16(0)$ & $0.037 \pm 0.001(0.002)$ \\
\hline & \multicolumn{3}{|c|}{ Salinity, $51.534 \%$} & & & \\
\hline & Average $^{\mathrm{a}, \mathrm{b}}$ & $N^{\mathrm{c}}$ & Eq. $(23)^{\mathrm{d}, \mathrm{e}}$ & & & \\
\hline 276.15 & $0.081 \pm 0.003(0.005)$ & $10(0)$ & $0.084 \pm 0.002(0.004)$ & & & \\
\hline 278.35 & $0.077 \pm 0.003(0.005)$ & $15(0)$ & $0.078 \pm 0.002(0.004)$ & & & \\
\hline 283.65 & $0.067 \pm 0.001(0.003)$ & $9(1)$ & $0.067 \pm 0.001(0.002)$ & & & \\
\hline 288.65 & $0.059 \pm 0.002(0.003)$ & $14(1)$ & $0.059 \pm 0.001(0.002)$ & & & \\
\hline 293.45 & $0.052 \pm 0.001(0.002)$ & $7(3)$ & $0.052 \pm 0.001(0.002)$ & & & \\
\hline 298.15 & $0.047 \pm 0.002(0.003)$ & $15(0)$ & $0.047 \pm 0.001(0.002)$ & & & \\
\hline 303.05 & $0.042 \pm 0.001(0.002)$ & $8(0)$ & $0.042 \pm 0.001(0.002)$ & & & \\
\hline 307.95 & $0.038 \pm 0.002(0.003)$ & $12(0)$ & $0.038 \pm 0.001(0.002)$ & & & \\
\hline 312.65 & $0.036 \pm 0.001(0.002)$ & $7(1)$ & $0.035 \pm 0.001(0.002)$ & & & \\
\hline
\end{tabular}

${ }^{\mathrm{a}}$ Errors are $2 \sigma$ for the average only. ${ }^{\mathrm{b}}$ Number in parentheses represents an error reflecting $2 \sigma$ for the average plus potential systematic bias $( \pm 2 \%)$. ${ }^{\mathrm{c}}$ Number in parentheses represents number of experimental runs excluded for the average. ${ }^{\mathrm{d}}$ Errors are $95 \%$ confidence level for the regression only. ${ }^{\mathrm{e}}$ Number in parentheses represents an error reflecting errors at the $95 \%$ confidence level for the regression plus potential systematic bias $( \pm 2 \%)$.

8.921, 21.520, and $51.534 \%$. The $K_{\text {eq }}(T)$ value at an aseawater salinity of $S$ in per mill is represented by $K_{\text {eq }}^{\mathrm{S}}(T)$ hereafter. Table 3 lists the $K_{\text {eq }}^{\mathrm{S}}(T)$ values.

Figure 4 plots the $K_{\text {eq }}^{\mathrm{S}}(T)$ values against $100 / T$. The plots indicate a clear salting-out effect on $\mathrm{CH}_{2} \mathrm{~F}_{2}$ solubility in a-seawater: that is, the solubility of $\mathrm{CH}_{2} \mathrm{~F}_{2}$ in aseawater decreased with increasing a-seawater salinity. For example, the solubility of $\mathrm{CH}_{2} \mathrm{~F}_{2}$ in a-seawater at a salinity of $36.074 \%$ o was $0.74-0.78$ times the solubility in water at 3.0 to $39.5^{\circ} \mathrm{C}$.
In general, the salting-out effect on nonelectrolyte solubility in an aqueous salt solution of ionic strength $I$ can be determined empirically by means of the Sechenov equation:

$\ln \left(K_{\mathrm{H}}(T) / K_{\mathrm{eq}}^{\mathrm{I}}(T)\right)=k_{\mathrm{I}} I$,

where $K_{\text {eq }}^{\mathrm{I}}(T)$ is the $K_{\mathrm{eq}}(T)$ at ionic strength $I$ in $\mathrm{mol} \mathrm{kg}^{-1}$; and $k_{\mathrm{I}}$ is the Sechenov coefficient for the molality- and natural-logarithm-based Sechenov equation and is independent of $I$ (Clegg and Whitfield, 1991). For a-seawater, a sim- 


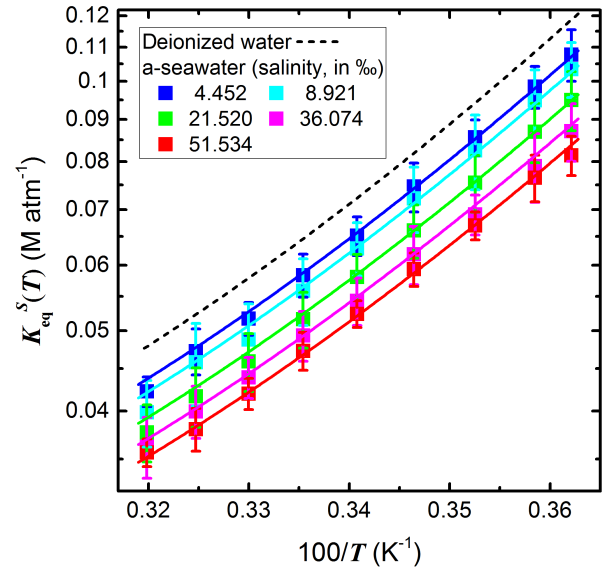

Figure 4. Van't Hoff plot of the $K_{\mathrm{eq}}^{\mathrm{S}}$ values for a-seawater at each salinity. Dashed curve represents the $K_{\mathrm{H}}$ values by Eq. (13). Solid curves represent the fitting obtained using Eq. (23). Error bars of the data represent $2 \sigma$ for the average plus potential systematic bias $( \pm 2 \%)$

ilar relationship between $K_{\mathrm{eq}}^{\mathrm{S}}(T)$ and $S$ is expected:

$\ln \left(K_{\mathrm{H}}(T) / K_{\mathrm{eq}}^{\mathrm{S}}(T)\right)=k_{\mathrm{S}} S$,

where $k_{\mathrm{S}}$ is the Sechenov coefficient for the salinity- and natural-logarithm-based Sechenov equation and is independent of $S$. Figure 5 plots $\ln \left(K_{\mathrm{H}}(T) / K_{\text {eq }}^{\mathrm{S}}(T)\right)$ against $S$ at each temperature. Table $\mathrm{S} 2$ lists values of $k_{\mathrm{S}}$ determined by fitting the data at each temperature by the use of Eq. (17). If the $K_{\text {eq }}^{\mathrm{S}}(T)$ values obeyed Eq. (17), the data at each temperature in Fig. 5 would fall on a straight line passing through the origin, but they do not. Figure 5 reveals that the salinity dependence of $\mathrm{CH}_{2} \mathrm{~F}_{2}$ solubility in a-seawater cannot be represented by Eq. (17).

When the same data were plotted on a log-log graph (Fig. S9), a line with a slope of about 0.5 was obtained by linear regression. This result suggests that $\ln \left(K_{\mathrm{H}}(T) / K_{\text {eq }}^{\mathrm{S}}(T)\right)$ varied according to Eq. (18):

$\ln \left(K_{\mathrm{H}}(T) / K_{\mathrm{eq}}^{\mathrm{S}}(T)\right)=k_{\mathrm{s}_{1}} \times S^{0.5}$.

Values of $k_{\mathrm{s}_{1}}$ may be represented by the following function of $T$ :

$k_{\mathrm{s}_{1}}=b_{1}+b_{2} \times\left(\frac{100}{T}\right)$.

Parameterizations of $b_{1}$ and $b_{2}$ obtained by fitting all the $\ln \left(K_{\mathrm{H}}(T) / K_{\mathrm{eq}}^{\mathrm{S}}(T)\right)$ and $S$ data at each temperature simultaneously by means of the nonlinear least-squares method gives Eq. (20).

$\ln \left(K_{\mathrm{H}}(T) / K_{\mathrm{eq}}^{\mathrm{S}}(T)\right)=\left(0.0127+0.0099 \times\left(\frac{100}{T}\right)\right) \times S^{0.5}$
The standard deviation for each fitting coefficient in Eq. (19) is as follows: $\delta b_{1}=0.0106 ; \delta b_{2}=0.0031$.

Since $2 \times \delta b_{1}>b_{1}$, the parameterization by Eq. (19) may be overworked. Accordingly, all the $\ln \left(K_{\mathrm{H}}(T) / K_{\mathrm{eq}}^{\mathrm{S}}(T)\right)$ and $S$ data at each temperature are fitted simultaneously using Eq. (21) instead of Eq. (19). The nonlinear least-squares method gives Eq. (22).

$k_{\mathrm{s}_{1}}=b_{2} \times\left(\frac{100}{T}\right)$

$\ln \left(K_{\mathrm{H}}(T) / K_{\mathrm{eq}}^{\mathrm{S}}(T)\right)=0.134 \times\left(\frac{100}{T}\right) \times S^{0.5}$

The standard deviation for the fitting coefficient in Eq. (21) is as follows: $\delta b_{2}=0.001$. As seen in Fig. 5, Eqs. (21) and (22) reproduced the data well.

$\ln \left(K_{\mathrm{H}}(T) / K_{\mathrm{eq}}^{\mathrm{S}}(T)\right)$ depends on $S^{0.5}$ and follows Eq. (22) rather than the Sechenov dependence (Eq. 17). Table S2 compares values of $K_{\text {eq }}^{\mathrm{S}}$ calculated using Eq. (22) with those by Eq. (17). The difference between these values of $K_{\text {eq }}^{\mathrm{S}}$ at $35 \%$ of salinity was within $3 \%$ of the $K_{\text {eq }}^{\mathrm{S}}$ value. Decreases in values of $K_{\text {eq }}^{\mathrm{S}}$ are calculated to be $7-8$ and $4 \%$, respectively, by Eqs. (17) and (22) as salinity of a-seawater increases from 30 to $40 \%$ at each temperature.

The reason for this salting-out effect of $\mathrm{CH}_{2} \mathrm{~F}_{2}$ solubility in a-seawater is not clear. Specific properties of $\mathrm{CH}_{2} \mathrm{~F}_{2}$ - small molecular volume, which results in little work (free energy) for cavity creation (Graziano, 2004, 2008), and large solute-solvent attractive potential energy in water and aseawater - may cause deviation from the Sechenov relationship (see the Supplement).

In Eq. (22), $K_{\mathrm{H}}(T)$ is represented by Eq. (13), as described in Sect. 3.1. Therefore, $K_{\text {eq }}^{\mathrm{S}}(T)$ is represented by Eq. (23):

$$
\begin{aligned}
\ln \left(K_{\text {eq }}^{\mathrm{S}}(T)\right) & =-49.71+\left(77.70-0.134 \times S^{0.5}\right) \times\left(\frac{100}{T}\right) \\
& +19.14 \times \ln \left(\frac{T}{100}\right) .
\end{aligned}
$$

The values calculated with Eq. (23) are indicated by the solid curves in Fig. 4 and are listed in Table 3. Table 3 lists errors at the $95 \%$ confidence level for the regression. These errors (error 23 ) are calculated using Eq. (24):

$\operatorname{error}_{23}=K_{\mathrm{eq}}^{\mathrm{S}} \times \sqrt{\left(\frac{\text { error }_{13}}{K_{\mathrm{H}}}\right)^{2}+\left(\frac{\text { error }_{22}}{K_{\mathrm{eq}}^{\mathrm{S}}}\right)^{2}}$,

where error 13 represents errors at the $95 \%$ confidence level for the regression by Eq. (12); error 22 represents errors at the $95 \%$ confidence level for the regression by Eq. (21). Table 3 also lists errors due to errors at the $95 \%$ confidence level for the regression plus potential systematic bias $( \pm 2 \%)$. Equation (23) reproduced the experimentally determined values of $K_{\mathrm{H}}(T)$ and $K_{\mathrm{eq}}^{\mathrm{S}}(T)$ within the uncertainty of these experimental runs. 

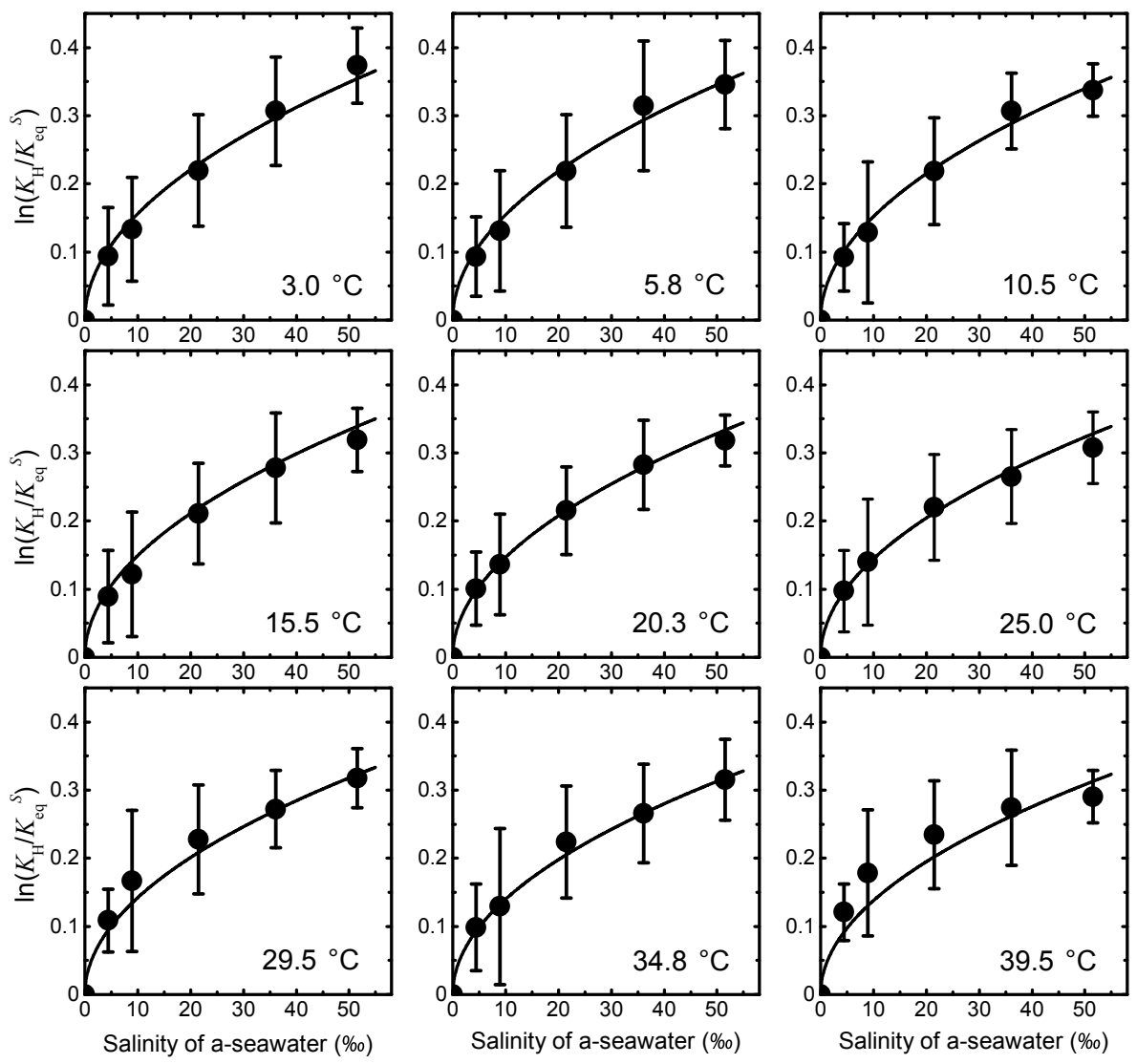

Figure 5. Plots of $\ln \left(K_{\mathrm{H}}(T) / K_{\mathrm{eq}}^{\mathrm{S}}(T)\right)$ vs. salinity in a-seawater at each temperature. Solid curves represent the fitting obtained using Eq. (22). Error bars represent errors reflecting $2 \sigma$ for the average plus potential systematic bias $( \pm 2 \%)$ of $K_{\text {eq }}^{\mathrm{S}}$.

\subsection{Dissolution of $\mathrm{CH}_{2} \mathrm{~F}_{2}$ in the ocean mixed layer and its influence on estimates of $\mathrm{CH}_{2} \mathrm{~F}_{2}$ emissions}

The solubility of $\mathrm{CH}_{2} \mathrm{~F}_{2}$ in a-seawater can be represented as a function of temperature and salinity relevant to the ocean (Eq. 23). Monthly averaged equilibrium fractionation values of $\mathrm{CH}_{2} \mathrm{~F}_{2}$ between the atmosphere and the ocean $\left(R_{\mathrm{m}}\right.$ in $\mathrm{Gg} \mathrm{patm}^{-1}$, where patm is $\left.10^{-12} \mathrm{~atm}\right)$ in which the ocean mixed layer is at solubility equilibrium with the atmosphere are estimated as follows. If we divide the global ocean into $0.25^{\circ} \times 0.25^{\circ}$ grids, $R_{\mathrm{m}}$ can be estimated from the sum of the equilibrium fractionation values from the gridded cells:

$R_{\mathrm{m}}=\frac{m_{\mathrm{d}, \mathrm{m}}}{P_{\mathrm{a}}}=Q \sum_{i=-360}^{i=360} \sum_{j=-720}^{j=720} K_{\mathrm{eq}}^{\mathrm{S}}(T) d_{i, j, m} A_{i, j, m}$,

where $m_{\mathrm{d}, \mathrm{m}}$, in gigagrams, is the amount of $\mathrm{CH}_{2} \mathrm{~F}_{2}$ dissolved in the ocean mixed layer; $p_{\mathrm{a}}$, in $10^{-12} \mathrm{~atm}$, is the $\mathrm{CH}_{2} \mathrm{~F}_{2}$ partial pressure in the air; $d_{i, j, m}$ is the monthly mean depth, in meters, of the ocean mixed layer in each grid cell; $A_{i, j, m}$ is the oceanic area, in square meters, in each grid cell; $Q$ is a conversion factor (with a value of 52); $m$ is the month index; and $i$ and $j$ are the latitude and longitude indices. We obtained monthly $0.25^{\circ} \times 0.25^{\circ}$ gridded sea surface temperatures and sea surface salinities from WOA V2 2013 data collected at $10 \mathrm{~m}$ depth from 2005 to 2012 (https://www.nodc. noaa.gov/OC5/woa13/woa13data.html; Boyer et al., 2013) and monthly $2^{\circ} \times 2^{\circ}$ gridded mean depths of the ocean mixed layer from mixed layer depth climatology and other related ocean variables in temperature with a fixed threshold criterion $\left(0.2^{\circ} \mathrm{C}\right)$ (http://www.ifremer.fr/cerweb/; de Boyer Montégut et al., 2004). Values of $A_{i, j, m}$ were estimated to be equal to the area of each grid cell in which both gridded data were unmasked.

Figure 6 shows the $R_{\mathrm{m}}$ values for the global and the semihemispheric atmosphere. Values of $R_{\mathrm{m}}$ for the global atmosphere are between 0.057 and $0.096 \mathrm{Gg} \mathrm{patm}^{-1}$. Because $10^{-12}$ atm of $\mathrm{CH}_{2} \mathrm{~F}_{2}$ in the global atmosphere corresponds to $9.4 \mathrm{Gg}$ of atmospheric burden of $\mathrm{CH}_{2} \mathrm{~F}_{2}, 0.6$ to $1.0 \%$ of the atmospheric burden resides in the ocean mixed layer when that layer is at solubility equilibrium with the atmosphere. The magnitude of "buffering" of the atmospheric burden of $\mathrm{CH}_{2} \mathrm{~F}_{2}$ by the additional $\mathrm{CH}_{2} \mathrm{~F}_{2}$ in ocean surface waters is therefore realistically limited to only about $1 \%$ globally. However, such buffering would be more effective in each lower-tropospheric semi-hemisphere of the AGAGE 12-box 


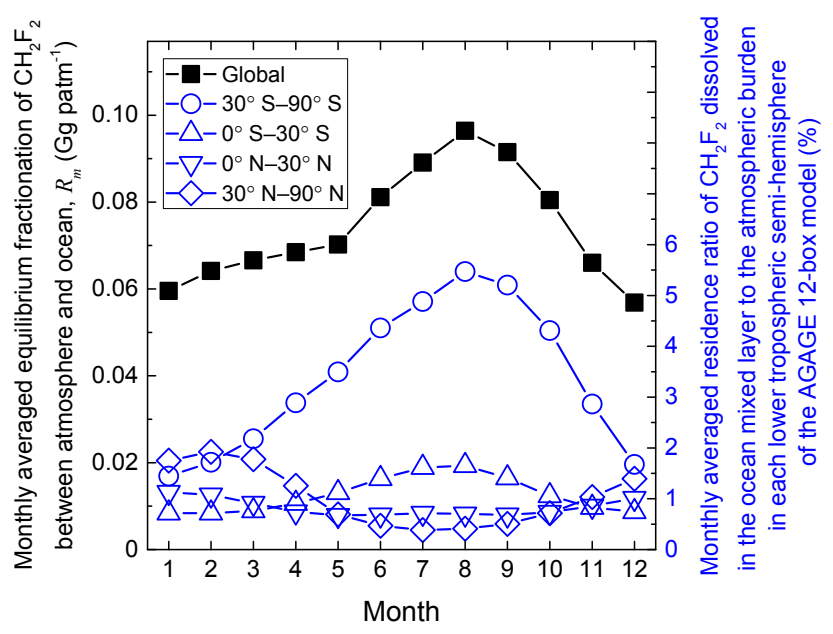

Figure 6. Plots of monthly averaged equilibrium fractionation of $\mathrm{CH}_{2} \mathrm{~F}_{2}$ between atmosphere and ocean, $R_{\mathrm{m}}\left(\mathrm{Gg} p a t m^{-1}\right)$ in the global and the semi-hemispheric atmosphere. Right vertical axis represents the residence ratio of $\mathrm{CH}_{2} \mathrm{~F}_{2}$ in the ocean, instead of $R_{\mathrm{m}}$, for each lower-tropospheric semi-hemisphere of the AGAGE 12-box model.

model, which has been used for a top-down estimate of $\mathrm{CH}_{2} \mathrm{~F}_{2}$ emissions. The right vertical axis of Fig. 6 represents the residence ratios of $\mathrm{CH}_{2} \mathrm{~F}_{2}$ dissolved in the ocean mixed layer for each lower-tropospheric semi-hemispheric atmosphere of the AGAGE 12-box model. The residence ratios were calculated on the assumption that $10^{-12}$ atm of $\mathrm{CH}_{2} \mathrm{~F}_{2}$ corresponds to $1.2 \mathrm{Gg}$ of atmospheric burden of $\mathrm{CH}_{2} \mathrm{~F}_{2}$ in each lower-tropospheric semi-hemisphere. As seen in Fig. 6, in the southern semi-hemispheric lower troposphere (30$90^{\circ} \mathrm{S}$ ), at least $5 \%$ of the atmospheric burden of $\mathrm{CH}_{2} \mathrm{~F}_{2}$ would reside in the ocean mixed layer in the winter, and the annual variance of the $\mathrm{CH}_{2} \mathrm{~F}_{2}$ residence ratio would be $4 \%$. These ratios are, in fact, upper limits because $\mathrm{CH}_{2} \mathrm{~F}_{2}$ in the ocean mixed layer may be undersaturated. It takes days to a few weeks after a change in temperature or salinity for oceanic surface mixed layers to come to equilibrium with the present atmosphere, and equilibration time increases with the depth of the surface mixed layer (Fine, 2011). In the estimation using the gridded data here, $>90 \%$ of $\mathrm{CH}_{2} \mathrm{~F}_{2}$ in the ocean mixed layer would reside in less than $300 \mathrm{~m}$ depth (Tables S4-S7).

Haine and Richards (1995) demonstrated that seasonal variation in ocean mixed layer depth was the key process which affected undersaturation and supersaturation of chlorofluorocarbon 11 (CFC-11), CFC-12, and CFC-113 by the use of a one-dimensional slab mixed model. As described above, $>90 \%$ of $\mathrm{CH}_{2} \mathrm{~F}_{2}$ in the ocean mixed layer is expected to reside in less than $300 \mathrm{~m}$ depth. According to the model calculation results by Haine and Richards (1995), saturation of $\mathrm{CH}_{2} \mathrm{~F}_{2}$ would be $>0.9$ for the ocean mixed layer with less than $300 \mathrm{~m}$ depth. The saturation of $\mathrm{CH}_{2} \mathrm{~F}_{2}$ in the ocean mixed layer is thus estimated to be at least 0.8 . In the southern semi-hemispheric lower troposphere $\left(30-90^{\circ} \mathrm{S}\right)$, therefore, at least $4 \%$ of the atmospheric burden of $\mathrm{CH}_{2} \mathrm{~F}_{2}$ would reside in the ocean mixed layer in the winter, and the annual variance of the $\mathrm{CH}_{2} \mathrm{~F}_{2}$ residence ratio would be $3 \%$.

In the Southern Hemisphere, $\mathrm{CH}_{2} \mathrm{~F}_{2}$ emission rates are much lower than in the Northern Hemisphere. Hence, dissolution of $\mathrm{CH}_{2} \mathrm{~F}_{2}$ in the ocean, even if dissolution is reversible, may influence estimates of $\mathrm{CH}_{2} \mathrm{~F}_{2}$ emissions derived from long-term observational data on atmospheric concentrations of $\mathrm{CH}_{2} \mathrm{~F}_{2}$; in particular, consideration of dissolution of $\mathrm{CH}_{2} \mathrm{~F}_{2}$ in the ocean may affect estimates of $\mathrm{CH}_{2} \mathrm{~F}_{2}$ emissions in the Southern Hemisphere and their seasonal variability because of slow rates of inter-hemispheric transport and a small portion of the $\mathrm{CH}_{2} \mathrm{~F}_{2}$ emissions in the Southern Hemisphere compared to the total emissions.

\section{Conclusion}

The solubility of $\mathrm{CH}_{2} \mathrm{~F}_{2}$ in aqueous salt solutions relevant to seawater can be represented as a function of temperature and salinity, as shown in Eq. (23). The relationship between $\mathrm{CH}_{2} \mathrm{~F}_{2}$ solubility and the salinity of the artificial seawater was found to be unusual in that the excessive free energy for dissolution depended predominantly on the 0.5 power of salinity. By using the solubility of $\mathrm{CH}_{2} \mathrm{~F}_{2}$ determined in this study, the magnitude of buffering of the atmospheric burden of $\mathrm{CH}_{2} \mathrm{~F}_{2}$ by the additional $\mathrm{CH}_{2} \mathrm{~F}_{2}$ in ocean surface waters is estimated to be realistically limited to only about $1 \%$ globally; however, in the southern semi-hemispheric lower troposphere $\left(30-90^{\circ} \mathrm{S}\right)$ of the AGAGE 12-box model, the atmospheric burden of $\mathrm{CH}_{2} \mathrm{~F}_{2}$ is estimated to reside in the ocean mixed layer at at least $4 \%$ in the winter and at $1 \%$ in the summer. Hence, it may be necessary that dissolution of $\mathrm{CH}_{2} \mathrm{~F}_{2}$ in the ocean be taken into consideration to derive $\mathrm{CH}_{2} \mathrm{~F}_{2}$ emissions in the Southern Hemisphere and their seasonal variability from long-term observational data on atmospheric concentrations of $\mathrm{CH}_{2} \mathrm{~F}_{2}$.

Data availability. The data are available on request from Shuzo Kutsuna (s-kutsuna@aist.go.jp).

\section{The Supplement related to this article is available online at https://doi.org/10.5194/acp-17-7495-2017-supplement.}

Competing interests. The author declares that they have no conflict of interest.

Acknowledgements. I am grateful to an anonymous referee for suggesting an equation for fitting the data. 
Edited by: R. Sander

Reviewed by: two anonymous referees

\section{References}

Anderson, G. K.: A thermodynamic study of the (difluoromethane + water) system, J. Chem. Thermodyn., 43, 13311335, https://doi.org/10.1016/j.jct.2011.03.020, 2011.

Boyer, T.P., Antonov, J. I., Baranova, O. K., Coleman, C., Garcia, H. E., Grodsky, A., Johnson, D. R., Locarnini, R. A., Mishonov, A. V., O'Brien, T. D., Paver, C. R., Reagan, J. R., Seidov, D., Smolyar, I. V., and Zweng, M. M.: World Ocean Database 2013, in: NOAA Atlas NESDIS 72, Technical Edn., edited by: Levitus, S., and Mishonov, A., NOAA, Silver Spring, MD, 209 pp., https://doi.org/10.7289/V5NZ85MT, 2013.

Brockbank, S. A., Russon, J. L., Giles, N. F., Rowley, R. L., and Wilding, W. V.: Infinite dilution activity coefficients and Henry's law constants of compounds in water using the inert gas stripping method, Fluid Phase Equil., 348, 45-51, https://doi.org/10.1016/j.fluid.2013.03.023, 2013.

Carpenter, L. J., Reimann, S., Burkholder, J. B., Clerbaux, C., Hall, B. D., Hossaini, R., Laube, J. C., and Yvon-Lewis, S. A.: Ozone-Depleting Substances (ODSs) and Other Gases of Interest to the Montreal Protocol, in: chap. 1, Scientific Assessment of Ozone Depletion: 2014, Global Ozone Research and Monitoring Project 55, World Meteorological Organization, Geneva, Switzerland, 2014.

Clarke, E. C. W. and Glew, D. N.: Evaluation of thermodynamic functions from equilibrium constants, Trans. Faraday Soc., 134, 539-547, https://doi.org/10.1039/TF9666200539, 1965.

Clegg, S. L. and Whitfield, M.: Activity coefficients in natural waters, in: chap. 6, Activity coefficients in electrolyte solutions, 2nd Edn., edited by: Pitzer, K. S., CRC Press, Boca Raton, FL, 279-434, 1991.

Clever, H. L., Battino, R., Clever, H. L., Jaselskis, B., Clever, H. L., Yampol'skii, Y. P., Jaselskis, B., Scharlin, P., and Young, C. L.: IUPAC-NIST Solubility Data Series. 80. Gaseous fluorides of boron, nitrogen, sulfur, carbon, and silicon and solid xenon fluorides in all solvents, J. Phys. Chem. Ref. Data, 34, 201-438, https://doi.org/10.1063/1.1794762, 2005.

Cunnold, D. M., Fraser, P. J., Weiss, R. F., Prinn, R. G., Simmonds, P. G., Miller, B. R., Alyea, F. N., and Crawford, A. J.: global trends and annual releases of $\mathrm{CCl}_{3} \mathrm{~F}$ and $\mathrm{CCl}_{2} \mathrm{~F}_{2}$ estimated from ALE/GAGE and other measurements from July 1978 to June 1991, J. Geophys. Res., 99, 1107-1126, https://doi.org/10.1029/93JD02715, 1994.

de Boyer Montégut, C., Madec, G., Fischer, A. S., Lazar, A., and Iudicone, D.: Mixed layer depth over the global ocean: an examination of profile data and a profile-based climatology, J. Geophys. Res., 109, C12003, https://doi.org/10.1029/2004JC002378, 2004.

Ettre, L., Welter, C., and Kolb, B.: Determination of gas-liquid partition coefficients by automatic equilibrium headspace-gas chromatography utilizing the phase ratio variation method, Chromatographia, 35, 73-84, https://doi.org/10.1007/BF02278560, 1993.
Fine, R. A.: Observations of CFCs and $\mathrm{SF}_{6}$ as ocean tracers, Annu. Rev. Mar. Sci., 3, 173-195, https://doi.org/10.1146/annurev.marine.010908.163933, 2011.

Graziano, G.: Case study of enthalpy-entropy noncompensation, J. Chem. Phys., 120, 4467-4471, https://doi.org/10.1063/1.1644094, 2004.

Graziano, G.: Salting out of methane by sodium chloride: A scaled particle theory study, J. Chem. Phys., 129, 084506, https://doi.org/10.1063/1.2972979, 2008.

Haine, T. W. N. and Richards, K. J.: The influence of the seasonal mixed layer on oceanic uptake of CFCs, J. Geophys. Res., 100, 10727-10744, https://doi.org/10.1029/95JC00629, 1995.

Hilal, S. H., Ayyampalayam, S. N., and Carreira, L. A.: Air-liquid partition coefficient for a diverse set of organic compounds: Henry's law constant in water and hexadecane. Environ. Sci. Technol., 42, 9231-9236, https://doi.org/10.1021/es8005783, 2008.

IPCC: Climate change 2013: the physical science basis, in: Contribution of Working group I to the fifth assessment report of the Intergovernmental panel on climate change, edited by: Stocker, T. F., Qin, D., Plattner, G.-K., Tignor, M., Allen, S. K., Boschung, J., Nauels, A., Xia, Y. Bex, V., and Midgley, P. M., Cambridge University Press, Cambridge, UK and New York, NY, USA, 1535 pp., 2013.

Krummen, M., Gruber, D., and Gmehling, J.: Measurement of activity coefficients at infinite dilution in solvent mixtures using the dilutor technique, Ind. Eng. Chem. Res., 39, 2114-2123, https://doi.org/10.1021/ie990830p, 2000.

Kühne, R., Ebert, R.-U., and Schüürmann, G.: Prediction of the temperature dependency of Henry's law constant from chemical structure, Environ. Sci. Technol., 39, 6705-6711, https://doi.org/10.1021/es050527h, 2005.

Kutsuna, S.: Determination of rate constants for aqueous reactions of HCFC-123 and HCFC-225ca with $\mathrm{OH}^{-}$along with Henry's law constants of several HCFCs, Int. J. Chem. Kinet., 45, 440 451, https://doi.org/10.1002/kin.20780, 2013.

Kutsuna, S. and Hori, H.: Experimental determination of Henry's law constant of perfluorooctanoic acid (PFOA) at $298 \mathrm{~K}$ by means of an inert-gas stripping method with a helical plate, Atmos. Environ., 42, 8883-8892, https://doi.org/10.1016/j.atmosenv.2008.09.008, 2008.

Lunt, M. F., Rigby, M., Ganesan, A. L., Manning, A. J., Prinn, R. G., O'Doherty, S., Mühle, J., Harth, C. M., Salameh, P. K., Arnold, T., Weiss, R. F., Saito, T., Yokouchi, Y., Krummel, P. B., Steele, L. P., Fraser, P. J., Li, S., Park, S., Reimann, S., Vollmer, M. K., Lunder, C., Hermansen, O., Schmidbauer, N., Maione, M., Arduini, J., Young, D., and Simmonds, P. G.: Reconciling reported and unreported HFC emissions with atmospheric observations, P. Natl. Acad. Sci. USA, 112, 5927-5931, https://doi.org/10.1073/pnas.1420247112, 2015.

Maaßen, S.: Experimentelle Bestimmung und Korrelierung von Verteilungskoeffizienten in verdünnten Lösungen, $\mathrm{PhD}$ thesis, Technische Universität Berlin, Berlin, Germany, 1995.

Mackay, D., Shiu, W. Y., and Sutherland, R. P.: Determination of air-water Henry's law constants for hydrophobic pollutants, Environ. Sci. Technol., 13, 333-337, https://doi.org/10.1021/es60151a012, 1979. 
Miguel, A. A. F., Ferreira, A. G. M., and Fonseca, I. M. A.: Solubilities of some new refrigerants in water, Fluid Phase Equil., 173, 97-107, https://doi.org/10.1016/S0378-3812(00)00390-3, 2000.

Montzka, S. A., McFarland, M., Andersen, S. O., Miller, B. R., Fahey, D. W., Hall, B. D., Hu, L., Siso, C., and Elkins, J. W.: Recent trends in global emissions of hydrochlorofluorocarbons and hydrofluorocarbons: reflecting on the 2007 Adjustments to the Montreal Protocol, J. Phys. Chem. A, 119, 4439-4449, https://doi.org/10.1021/jp5097376, 2015.

O’Doherty, S., Rigby, M., Mühle, J., Ivy, D. J., Miller, B. R., Young, D., Simmonds, P. G., Reimann, S., Vollmer, M. K., Krummel, P. B., Fraser, P. J., Steele, L. P., Dunse, B., Salameh, P. K., Harth, C. M., Arnold, T., Weiss, R. F., Kim, J., Park, S., Li, S., Lunder, C., Hermansen, O., Schmidbauer, N., Zhou, L. X., Yao, B., Wang, R. H. J., Manning, A. J., and Prinn, R. G.: Global emissions of HFC-143a $\left(\mathrm{CH}_{3} \mathrm{CF}_{3}\right)$ and HFC-32 $\left(\mathrm{CH}_{2} \mathrm{~F}_{2}\right)$ from in situ and air archive atmospheric observations, Atmos. Chem. Phys., 14, 9249-9258, https://doi.org/10.5194/acp-14-9249-2014, 2014.

Platford, R. F.: The activity coefficient of sodium chloride in seawater, J. Mar. Res., 23, 55-62, 1965.

Prinn, R. G., Weiss, R. F., Fraser, P. J., Simmonds, P. G., Cunnold, D. M., Alyea, F. N., O’Doherty, S., Salameh, P., Miller, B. R., Huang, J., Wang, R. H. J., Hartley, D. E., Harth, C., Steele, L. P., Sturrock, G., Midgley, P. M., and McCulloch, A.: A history of chemically and radiatively important gases in air deduced from ALE/GAGE/AGAGE, J. Geophys. Res.-Atmos., 105, 1775117792, https://doi.org/10.1029/2000JD900141, 2000.

Reichl, A.: Messung und Korrelierung von Gaslöslichkeiten halogenierter ohlenwasserstoffe, $\mathrm{PhD}$ thesis, Technische Universität Berlin, Berlin, Germany, 1995.
Rigby, M., Prinn, R. G., O’Doherty, S., Montzka, S. A., McCulloch, A., Harth, C. M., Mühle, J., Salameh, P. K., Weiss, R. F., Young, D., Simmonds, P. G., Hall, B. D., Dutton, G. S., Nance, D., Mondeel, D. J., Elkins, J. W., Krummel, P. B., Steele, L. P., and Fraser, P. J.: Re-evaluation of the lifetimes of the major CFCs and $\mathrm{CH}_{3} \mathrm{CCl}_{3}$ using atmospheric trends, Atmos. Chem. Phys., 13 2691-2702, https://doi.org/10.5194/acp-13-2691-2013, 2013.

Sander, R.: Compilation of Henry's law constants (version 4.0) for water as solvent, Atmos. Chem. Phys., 15, 4399-4981, https://doi.org/10.5194/acp-15-4399-2015, 2015.

Weiss, R. F.: The solubility of nitrogen, oxygen and argon in water and seawater, Deep-Sea Res., 17, 721-735, https://doi.org/10.1016/0011-7471(70)90037-9, 1970.

Weiss, R. F. and Price, B. A.: Nitrous oxide solubility in water and seawater, Mar. Chem., 8, 347-359, https://doi.org/10.1016/0304 4203(80)90024-9, 1980.

Yaws, C. L. (Ed.): Chemical Properties Handbook, McGraw-Hill Education, New York, NY, 1999.

Yaws, C. L. and Yang, H.-C.: Henry's law constant for compound in water, in: chap. 11, Thermodynamic and Physical Property Data, edited by: Yaws, C. L., Gulf Publishing, Houston, TX, 181-206, 1992.

Yvon-Lewis, S. A. and Butler, J. H.: Effect of oceanic uptake on atmospheric lifetimes of selected trace gases, J. Geophys. Res.-Atmos., 107, 4414, https://doi.org/10.1029/2001JD001267, 2002. 